\title{
Prevalence of pathogens causing subclinical mastitis in 15 dairy herds in the Republic of Ireland
}

\author{
Damien J. Barrett', Anne M. Healy', Finola C. Leonard ${ }^{2}$ and Michael L. Doherty' \\ ' Department of Large Animal Clinical Studies, Faculty of Veterinary Medicine, University College Dublin, Belfield, \\ Dublin 4. \\ 2 Department of Veterinary Microbiology and Parasitology, Faculty of Veterinary Medicine, University College \\ Dublin, Belfield, Dublin 4.
}

Milk samples from 285 cows in 15 dairy herds were collected for bacteriological analysis. Cows were selected on the basis of a somatic cell count (SCC) exceeding 200,000 cells per $\mathrm{ml}$ at the three most recent milk recordings prior to sampling. Staphylococcus aureus and Streptococcus uberis were the predominant isolates accounting for $21 \%(n=61)$ and $19 \%(n=53)$ of isolates, respectively. Streptococcus uberis was more frequently isolated from split-calving herds than from spring-calving herds and this difference was statistically significant $(P<0.005)$. Herds with suboptimal housing had a significantly greater prevalence of $S$. uberis than did herds where housing was adequate $(P<0.005)$. The isolation rates for $S$. aureus was significantly greater in herds where parlour hygiene was suboptimal $(P<0.05)$.

\section{Key words:}

Cows,

Subclinical mastitis, Pathogens.

Irish Veterinary Journal

58: $333-337$

\section{Introduction}

Mastitis is regarded as the most economically significant infectious disease affecting dairy cattle (Bradley, 2002). It causes economic loss through reduced production, veterinary costs, discarded milk, financial penalties from processors, increased labour, increased culling and mortality. In the United Kingdom, Kossaibati (2000) estimated the cost of a clinical case of mastitis to be $€ 175$ sterling ( $€ 277)$. In dealing with mastitis outbreaks it is important to establish the causative agent so that the most appropriate treatment and control regimes may be instigated.The identity of the causative agent is relevant to establishing the risk factors that have led to the development of mastitis on a particular farm.

Environmental pathogens are now the more common cause of clinical mastitis in the UK, and are a particular problem in low somatic cell count (SCC)herds (Bradley, 2002). Furthermore, the best estimates for average bulk SCC from the UK range from 160,000 to 180,000 cells per $\mathrm{ml}$ (Hillerton, 200I). In Ireland, comparable data on the aetiology

Corresponding author:

Damien J. Barrett

Centre for Veterinary Epidemiology and Risk Analysis,

Faculty of Veterinary Medicine, University College Dublin,

Dublin 4, Ireland.

Tel: +353 | 7166148

Fax: +353 | 7166147

Email:Damien.barrett@ucd.ie of subclinical mastitis has not been generated since the mid 1980s. A previous Irish study on 46 I cows in 64 herds subclinically infected with mastitis (Egan and O'Dowd, 1982) found that staphylococcal and streptococcal isolates accounted for up to $66 \%$ and $20 \%$ of quarter isolates, respectively. While anecdotal accounts from veterinary surgeons indicate that environmental mastitis is common in Ireland, the mean bulk milk SCC for Irish herds is estimated to be 300,000 cells per $\mathrm{ml}$ (Meaney, 200I), which indicates that contagious mastitis remains a problem in Irish dairy herds.

The objective of this study was to determine the prevalence of the various mastitis pathogens in 15 Irish dairy herds.

\section{Materials and methods}

The study was carried out on 15 dairy herds experiencing increased incidence of clinical mastitis and/or elevated somatic cell count (SCC).

Categories of herds

Spring-calving herds

During the course of the on-farm mastitis investigations, herds were designated spring-calving if all cows calved during the months from January until April.

Split-calving herds

Herds were designated as split-calving when a proportion of the herd calved in the autumn (from September to November, inclusive) and the remainder calved during the spring (January until April). 


\begin{tabular}{|c|c|c|c|c|c|c|c|c|c|c|c|}
\hline Farm & $\begin{array}{c}\text { No. of } \\
\text { samples }\end{array}$ & $\begin{array}{r}\text { No } \\
\text { growth }\end{array}$ & $\begin{array}{l}\text { Staph. } \\
\text { aureus }\end{array}$ & $\begin{array}{l}\text { Strep. } \\
\text { uberis }\end{array}$ & $\begin{array}{r}\text { Strep. } \\
\text { agalactiae }\end{array}$ & $\begin{array}{r}\text { Strep. } \\
\text { dysgalactiae }\end{array}$ & Mixed & $\begin{array}{r}\text { Coagulase- } \\
\text { negative } \\
\text { Staph. }\end{array}$ & Coliforms & $\begin{array}{r}\text { Minor } \\
\text { pathogens }\end{array}$ & Contaminants \\
\hline \multicolumn{12}{|c|}{ Split-calving herds } \\
\hline $\boldsymbol{A}$ & 36 & 14 (39) & I (3) & $13(36)$ & 0 & I (3) & 0 & I (3) & 0 & $3(9)$ & $3(9)$ \\
\hline D & 10 & $2(20)$ & $2(20)$ & $4(40)$ & 0 & 0 & I (10) & 0 & 0 & 0 & I (10) \\
\hline G & 6 & $3(50)$ & I (16) & $I(16)$ & 0 & 0 & $1(16)$ & 0 & 0 & 0 & 0 \\
\hline I & 31 & $13(42)$ & $5(16)$ & $8(26)$ & 0 & 0 & 0 & 0 & $2(6)$ & $3(10)$ & 0 \\
\hline$L$ & 16 & $3(19)$ & $6(38)$ & $3(19)$ & 0 & I (6) & I (6) & 0 & 0 & $2(13)$ & 0 \\
\hline$N$ & 11 & $3(27)$ & $2(18)$ & 0 & 0 & $2(18)$ & I (9) & I (9) & 0 & $2(18)$ & 0 \\
\hline Total & 110 & $38(34)$ & $17(15)$ & $29(26)$ & 0 & $4(4)$ & $4(4)$ & $2(2)$ & $2(2)$ & $10(9)$ & $4(4)$ \\
\hline \multicolumn{12}{|c|}{ Spring-calving herds } \\
\hline$E$ & 33 & $5(15)$ & $10(30)$ & $6(18)$ & 0 & 0 & $2(6)$ & $6(18)$ & 0 & $4(12)$ & 0 \\
\hline $\boldsymbol{F}$ & 20 & $3(15)$ & II (55) & $2(10)$ & 0 & 0 & 0 & $3(15)$ & 0 & I (5) & 0 \\
\hline$H$ & 6 & I (16) & $3(50)$ & 0 & 0 & 0 & I (I6) & I (16) & 0 & 0 & 0 \\
\hline$J$ & 37 & $14(38)$ & $7(19)$ & $7(19)$ & 0 & $2(5)$ & $2(5)$ & I (3) & $2(5)$ & $2(5)$ & 0 \\
\hline$\kappa$ & 24 & $6(25)$ & 7 (29) & 0 & 0 & 0 & 0 & $8(33)$ & & $3(13)$ & 0 \\
\hline$M$ & 11 & 0 & 0 & 0 & $7(64)$ & 0 & $2(18)$ & 0 & 0 & $2(18)$ & 0 \\
\hline 0 & 19 & $7(37)$ & 0 & 0 & 0 & 0 & I (5) & $4(21)$ & $3(16)$ & $4(21)$ & 0 \\
\hline Total & 175 & $41(25)$ & $42(24)$ & $24(14)$ & $7(4)$ & $2(1)$ & $12(7)$ & $24(14)$ & $7(4)$ & $16(9)$ & 0 \\
\hline Total & 285 & 77 (28) & 61 (2I) & 53 (19) & $7(2)$ & $6(2)$ & $16(6)$ & $26(9)$ & $9(3)$ & $26(9)$ & $4(1)$ \\
\hline
\end{tabular}

\section{Suboptimal housing}

Herds were assigned to the suboptimal housing category if deficiencies were uncovered in any of the following areas: cubicle number, cubicle cleaning, calving area, exposure to wind and rain, and prolonged periods spent on straw-bedded yards.

\section{Suboptimal parlour hygiene}

Herds were assigned to the suboptimal parlour hygiene category if two or more deficiencies relating to milking technique were identified. These deficiencies related to identification of mastitis, washing and not drying teats prior to milking, machine stripping, and absence of, or insufficient, post-milking teat disinfection.

Selection of cows

Cows were selected on the basis of a SCC exceeding 200,000 cells $/ \mathrm{ml}$ in their three most recent milk recordings. Somatic cell counts were measured using Fossometric cell counters.

\section{Collection of samples}

Milk samples were collected aseptically. Disposable gloves were worn throughout the sampling process. Teats were cleaned using chlorhexidine (Hibiscrub) and then wiped with $70 \%(v / v)$ ethanol. Quarter samples were taken from all selected cows. The first two squirts of milk were discarded. Sample jars were held at an angle of $45^{\circ}$ to the teat to avoid sample contamination. Sample tubes were identified by cow and quarter. The California Mastitis Test (CMT) was carried out on all samples using methods previously described by Schalm and Noorlander (1957). Samples scoring a 2+ or more were selected for microbiological analysis. If more than one quarter per cow was selected, then samples were pooled into composite samples to minimise cost. In all, samples from 285 cows were submitted for bacteriological analysis to the Diagnostic Laboratory, University Veterinary Hospital.

\section{Bacteriological examination}

\section{Routine culture}

Milk samples were plated directly on to sheep's blood agar, Edwards' medium and MacConkey II agar. The inoculated plates were incubated aerobically at $37^{\circ} \mathrm{C}$ and examined after 18 hours. If growth had not occurred at this time, they were incubated for a further 24 hours and re-examined. If growth had not occurred after 36 hours, the samples were deemed to be negative. If bacteria grew, the colonies were described and a Gram stain was performed. Colonies were tested for their oxidase and catalase activities. In the event of two or more major mastitis pathogens being isolated together, this was designated as a mixed growth. S. aureus, S. uberis, S. agalactiae, S. dysgalactiae, E. coli and coagulase-negative staphylococci were considered as major mastitis pathogens. Isolates other than these that were known to be mastitis pathogens were considered minor mastitis pathogens. Isolates not known to cause mastitis or not likely to have caused mastitis in the particular case were classified as contaminants.

\section{Entry of data and statistical analysis}

Data were entered in an Excel database (Microsoft Corporation, Seattle, Washington, USA). The chi-square test was used to examine differences in isolation rates between spring-calving and split-calving herds, between herds with suboptimal housing and those with adequate housing, and between herds with suboptimal parlour hygiene and herds where parlour hygiene was deemed to be adequate. 


\begin{tabular}{|c|c|c|c|c|c|c|c|c|c|c|}
\hline Farm & $\begin{array}{r}\text { No. of } \\
\text { samples }\end{array}$ & $\begin{array}{r}\text { No } \\
\text { Growth }\end{array}$ & $\begin{array}{l}\text { Staph. } \\
\text { aureus }\end{array}$ & $\begin{array}{l}\text { Strep. } \\
\text { uberis }\end{array}$ & $\begin{array}{c}\text { Strep. } \\
\text { agalactiae }\end{array}$ & $\begin{array}{r}\text { Strep. } \\
\text { dysgalactiae }\end{array}$ & Mixed & $\begin{array}{r}\text { Coagulase } \\
\text { negative } \\
\text { Staph. }\end{array}$ & Coliforms & $\begin{array}{r}\text { Minor } \\
\text { pathogens }\end{array}$ \\
\hline \multicolumn{11}{|c|}{ Adequate housing } \\
\hline B & 12 & 0 & $6(50)$ & 0 & 0 & 0 & $4(33)$ & $\mathrm{I}(\mathrm{I})$ & $I(13)$ & 0 \\
\hline $\mathrm{E}$ & 33 & $5(15)$ & $10(30)$ & $6(18)$ & 0 & 0 & $2(6)$ & $6(18)$ & 0 & $4(12)$ \\
\hline $\mathrm{F}$ & 20 & $3(15)$ & II (55) & $2(10)$ & 0 & 0 & 0 & $3(15)$ & 0 & I (5) \\
\hline $\mathrm{K}$ & 24 & $6(25)$ & $7(29)$ & 0 & 0 & 0 & 0 & $8(33)$ & 0 & $3(13)$ \\
\hline L & 16 & $3(19)$ & $6(38)$ & $3(19)$ & 0 & I (6) & I (6) & 0 & 0 & $2(13)$ \\
\hline M & 11 & 0 & 0 & 0 & $7(64)$ & 0 & $2(18)$ & 0 & 0 & $2(18)$ \\
\hline O & 19 & $7(37)$ & 0 & 0 & 0 & 0 & $3(16)$ & I (5) & $4(21)$ & $4(2 I)$ \\
\hline Total & 135 & $24(17)$ & $40(30)$ & II (8) & $7(11)$ & I (I) & $12(9)$ & $19(14)$ & $5(4)$ & $16(12)$ \\
\hline \multicolumn{11}{|c|}{ Suboptimal housing } \\
\hline A & 36 & $14(39)$ & I (3) & $13(36)$ & 0 & I (3) & 0 & I (3) & 0 & $6(18)$ \\
\hline C & 13 & $3(23)$ & 0 & $9(69)$ & 0 & 0 & 0 & 0 & I (8) & 0 \\
\hline $\mathrm{D}$ & 10 & $2(20)$ & $2(20)$ & $4(40)$ & 0 & 0 & I (10) & 0 & 0 & I (10) \\
\hline G & 6 & $3(50)$ & I (16) & I (16) & 0 & 0 & I (16) & 0 & 0 & 0 \\
\hline $\mathrm{H}$ & 6 & I (16) & $3(50)$ & 0 & 0 & 0 & I (16) & I (16) & 0 & 0 \\
\hline 1 & 31 & $13(42)$ & $5(16)$ & $8(26)$ & 0 & 0 & 0 & 0 & $2(6)$ & $3(10)$ \\
\hline J & 37 & $14(38)$ & $7(19)$ & $7(19)$ & 0 & $2(5)$ & $2(5)$ & I (3) & $2(5)$ & $2(5)$ \\
\hline $\mathrm{N}$ & 11 & $3(27)$ & $2(18)$ & 0 & 0 & $2(18)$ & I (9) & I (9) & 0 & $2(18)$ \\
\hline Total & 150 & $53(35)$ & $21(14)$ & $42(28)$ & 0 & $5(3)$ & $6(4)$ & $4(3)$ & $5(3)$ & $14(9)$ \\
\hline Total & 285 & $77(28)$ & $61(21)$ & $53(19)$ & $7(2)$ & $6(2)$ & $16(6)$ & $26(9)$ & $9(3)$ & $26(9)$ \\
\hline
\end{tabular}

\section{Results}

Bacterial isolates

The results of bacteriological examinations of the 285 milk samples are presented in Table I. Growth was not detected in $77(28 \%)$ of the samples. Staphylococcus aureus was found in samples from 12 herds and in 61 (21\%) of all the samples, while Streptococcus uberis was found in nine herds and in 19\% of all samples. Streptococcus agalactiae was found in one herd only: Farm M, where it was isolated from seven of II samples. Coagulase-negative staphylococci were isolated from 26 (9\%) of the samples and these were distributed amongst nine farms. Coliform bacteria were found on five farms and in nine (3\%) samples. Sixteen samples $(6 \%)$ had more than one isolate (mixed growth) and they were distributed among 10 herds. S. aureus and S. uberis were the predominant pathogens isolated from cultures with more than one isolate.

\section{Comparison of spring-calving herds with split-calving herds}

Differences were detected in the isolation rates between springcalving and split-calving herds, as outlined in Table I. There were statistically significant differences between the two groups in terms of negative sample rate $(\mathrm{P}<0.05)$ and of overall isolate pattern $(<0.00 \mathrm{I})$. Streptococcus uberis was isolated more frequently from split-calving herds than from spring-calving herds $(\mathrm{P}<0.005)$. The difference in isolation rate of $S$. aureus between spring-calving and split-calving herds was not statistically significant $(P>0.05)$, although $S$. aureus tended to be more prevalent in spring-calving herds.

The impact of suboptimal housing conditions

Suboptimal housing (Table 2) made an impact on the prevalence of subclinical mastitis. Isolation rate of $\mathrm{S}$. uberis was significantly greater $(P<0.005)$ in herds with suboptimal housing (found in six herds, in 42

samples) than in herds where housing was adequate (found in three herds, in II samples).

\section{Suboptimal parlour hygiene}

Differences were detected in the distribution of isolates amongst herds with suboptimal parlour hygiene when compared with isolates in herds where parlour hygiene was found to be adequate (Table 3). The isolation rates for $S$. aureus was significantly greater in herds where parlour hygiene was suboptimal $(\mathrm{P}<0.05)$. Also, there was a greater prevalence of $S$. uberis in herds where parlour hygiene was inadequate.

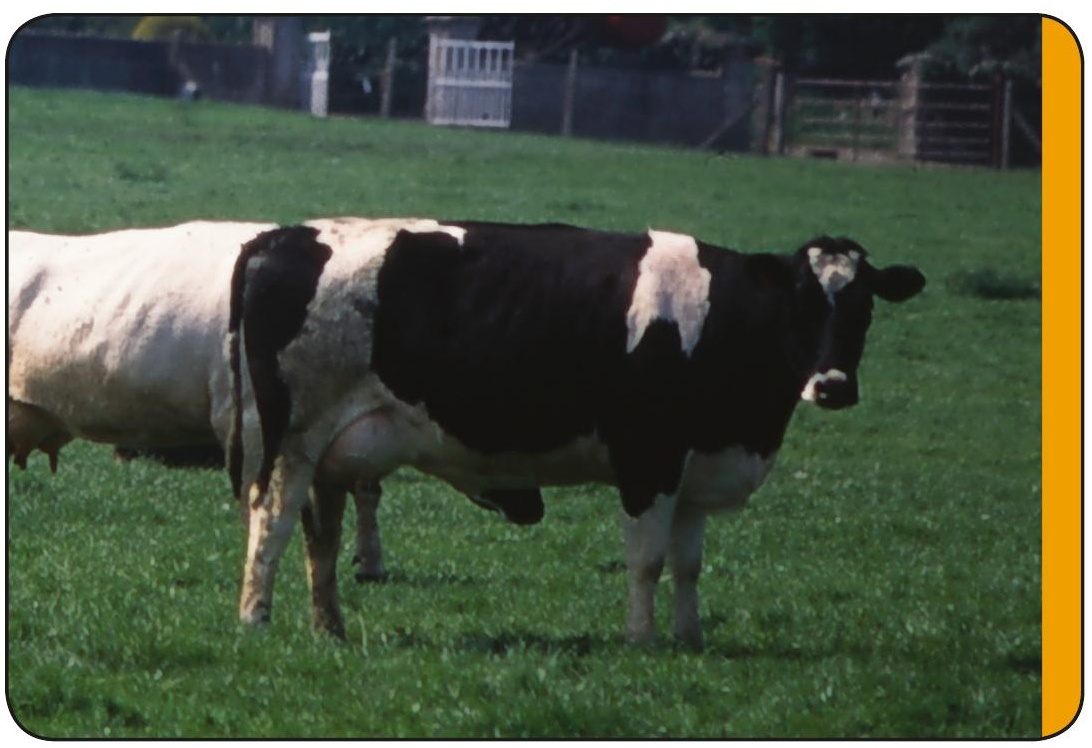

Mastitis is regarded as the most economically significant infectious disease affecting dairy cattle. 


\begin{tabular}{|c|c|c|c|c|c|c|c|c|c|c|}
\hline Farm & $\begin{array}{l}\text { No. of } \\
\text { samples }\end{array}$ & $\begin{array}{r}\text { No } \\
\text { growth }\end{array}$ & $\begin{array}{l}\text { Staph. } \\
\text { aureus }\end{array}$ & $\begin{array}{l}\text { Strep. } \\
\text { uberis }\end{array}$ & $\begin{array}{r}\text { Strep. } \\
\text { agalactiae }\end{array}$ & $\begin{array}{r}\text { Strep. } \\
\text { dysgalactiae }\end{array}$ & Mixed & $\begin{array}{l}\text { gulase- } \\
\text { legative } \\
\text { Staph. }\end{array}$ & Coliforms & $\begin{array}{r}\text { Minor } \\
\text { pathogens }\end{array}$ \\
\hline \multicolumn{11}{|c|}{ Adequate parlour hygiene } \\
\hline C & 13 & $3(23)$ & 0 & $9(69)$ & 0 & 0 & 0 & 0 & $\mathrm{I}(8)$ & 0 \\
\hline D & 10 & $2(20)$ & $2(20)$ & $4(40)$ & 0 & 0 & $\mathrm{I}(10)$ & 0 & 0 & I (10) \\
\hline G & 6 & $3(50)$ & I (16) & $1(16)$ & 0 & 0 & $1(16)$ & 0 & 0 & 0 \\
\hline $\mathrm{H}$ & 6 & $I(16)$ & $3(50)$ & 0 & 0 & 0 & $I(16)$ & $I(16)$ & 0 & 0 \\
\hline $\mathrm{N}$ & 11 & $3(27)$ & $2(18)$ & 0 & 0 & $2(18)$ & I (9) & I (9) & 0 & $2(18)$ \\
\hline O & 19 & $7(37)$ & 0 & 0 & 0 & 0 & $I(16)$ & $4(5)$ & $3(21)$ & $4(2 I)$ \\
\hline Total & 65 & $19(29)$ & $8(12)$ & $14(22)$ & 0 & $2(3)$ & $5(8)$ & $6(9)$ & $4(6)$ & $7(11)$ \\
\hline \multicolumn{11}{|c|}{ Suboptimal parlour hygiene } \\
\hline A & 36 & $14(39)$ & $\mathrm{I}(3)$ & $13(36)$ & 0 & I (3) & 0 & I (3) & 0 & $6(18)$ \\
\hline$E$ & 33 & $5(15)$ & $10(30)$ & $6(18)$ & 0 & 0 & $2(6)$ & $6(18)$ & 0 & $4(12)$ \\
\hline $\mathrm{F}$ & 20 & $3(15)$ & II (55) & $2(10)$ & 0 & 0 & 0 & $3(15)$ & 0 & I (5) \\
\hline I & 31 & $13(42)$ & $5(16)$ & $8(26)$ & 0 & 0 & 0 & 0 & $2(6)$ & $3(10)$ \\
\hline J & 37 & $14(38)$ & $7(19)$ & $7(19)$ & 0 & $2(5)$ & $2(5)$ & I (3) & $2(5)$ & $2(5)$ \\
\hline $\mathrm{K}$ & 24 & $6(25)$ & 7 (29) & 0 & 0 & 0 & 0 & $8(33)$ & 0 & $3(13)$ \\
\hline $\mathrm{L}$ & 16 & $3(19)$ & $6(38)$ & $3(19)$ & 0 & I (6) & I (6) & 0 & 0 & $2(13)$ \\
\hline M & 11 & 0 & 0 & 0 & 7 (64) & 0 & $2(18)$ & 0 & 0 & $2(18)$ \\
\hline Total & 220 & $58(26)$ & $53(24)$ & $39(18)$ & 7 (3) & $4(2)$ & II (5) & 20 (9) & $5(2)$ & $23(10)$ \\
\hline Total & 285 & 77 (28) & $61(21)$ & $52(18)$ & 7 (2) & $6(2)$ & $16(6)$ & 27 (9) & $9(3)$ & $28(10)$ \\
\hline
\end{tabular}

\section{Discussion}

Relatively up-to-date data on the aetiology of subclinical mastitis are available in other countries but not in Ireland, where the most recent data were generated in the mid-1980s. Management conditions in Ireland differ greatly from management systems in other countries; in particular, the predominance of grass-based milk production and the less severe price structure give rise to risk factors that differ greatly from those that pertain in the UK. With a predominately grass-based production, the majority of cows calve in the spring months to facilitate the production of milk off grass. Therefore, these cows will have a reduced exposure to risk factors for environmental mastitis when compared to cows that calve in the autumn months and produce the bulk of their milk while they are housed. Thus, there was a need to investigate a sample of Irish dairy herds to assess the prevalence of the various bacteria that give rise to mastitis and, in particular, to elevation in SCC. Such data are of use to those involved in maximising milk quality at farm level for the benefit of the producer processor and consumer.

Staphylococcus aureus was more prevalent in spring-calving herds $(24 \%$ of samples) than in split-calving herds ( $15 \%$ of samples) and it was recovered twice as frequently in herds where parlour hygiene was inadequate ( $24 \%$ of samples) than in herds where parlour hygiene was adequate (I2\% of samples). This is consistent with our understanding of the epidemiology of contagious pathogens. Bradley and Green (200I) attributed the low levels of S. aureus infection encountered in their study of clinical mastitis in Somerset dairy herds to widespread implementation of the Five-Point Plan, adopted to comply with more stringent bulk milk SCC requirements that, in turn, led to improved milk prices. This present study clearly indicates that $S$. aureus remains a significant cause of mastitis in Irish dairy herds. However, it is unlikely that standards will improve significantly until milk processors demand milk of a lower cell count.

Coagulase-negative staphylococci were isolated from 26 samples (9\%), comprising 24 samples (14\%) from spring-calving herds and two samples (2\%) from split-calving herds. As expected, the pattern of coagulase-negative staphylococci was similar to that of S. aureus across spring-calving and split-calving herds as well as in herds where suboptimal parlour hygiene was identified as a major problem. This is consistent with the current understanding that the factors predisposing to $S$. aureus infection may be similar to those that predispose to coagulase-negative staphylococci. Consequently, measures to control S. aureus infection should aid in the control of coagulase-negative staphylococci (Watts and Owens, 1989).

Infection of the udder by Streptococcus uberis is closely associated with poor housing conditions, especially with damp straw (Bramley, 1982). It was the second most frequently isolated bacterium in this study, being isolated from 53 (19\%) samples, which agrees with the study by Aungier (1985). However, there was a significantly greater prevalence $(\mathrm{P}<0.0 \mathrm{I})$ among split-calving herds $(26 \%)$ than in spring-calving herds (14\%); indeed, S. uberis was isolated from five of the six split-calving herds. These cows were calving early during the winter housing period and were exposed to the bacteria while lactating during the housed period. It was notable that the prevalence of $S$. uberis was greatest $(\mathrm{P}<0.00 \mathrm{I})$ where deficiencies in cow housing were identified.

S. agalactiae was isolated from only herd (Herd $M)$ and in that herd it accounted for $64 \%$ of isolates. Previously, Egan and O'Dowd (1982) had concluded that S. agalactiae was mainly associated with individual herd problems. Under-milking and poor milk let-down are known to predispose to infection with S. agalactiae; under-milking 
was identified as a problem in Herd M. While S. agalactiae may not be a very common cause of mastitis in Irish dairy herds it can cause considerable loss in individual herds (Edmondson, 1989).

S. dysgalatiae is part of the complex of bacteria that give rise to summer mastitis (Quinn et al., 2002); it was not a significant mastitiscausing pathogen in the herds under study.

It was expected that the prevalence of coliform bacteria in this study would be low, as the selection criteria identified cows with subclinical mastitis as opposed to clinical mastitis. Coliform mastitis is usually clinical in nature and of short duration (Smith, 1986). Although it is recognised that chronic coliform infections do exist (Eberart, 1984), it would be wise to interpret the prevalence of coliform bacteria in this present study with care. This is because coliform bacteria are not reliably cultured from milk, as samples can be easily contaminated (Hillerton et al., 1995). Composite samples, as was the case in this study, are more frequently contaminated (Smith, 1986).

Pathogens were not identified in 77 samples (27\%), which was a superior recovery rate to that of Aungier (1985) who failed to identify a pathogen in $47 \%$ of samples submitted from cows suffering subclinical mastitis. The different findings in the two studies may be explained by the fact that composite samples were cultured in the present study, increasing the isolation rate. The proportion of samples from which bacteria were not isolated was quite high when compared to previous studies involving cases of clinical mastitis; $15 \%$ (Bradley and Green, 200I) and I7\% (Milne et al., 2002). The difference in isolation rates between samples taken from clinical cases and subclinical cases may have arisen due to the sequestration of $S$. aureus in abscesses within the mammary gland and the consequential cyclical nature of bacterial shedding in subclinical mastitis (Sears et al., 1990).

\section{Conclusions}

S. aureus was the most significant cause of subclinical mastitis among the herds under study; the data indicate that $S$. aureus is a more significant problem among dairy herds producing milk for manufacturing than for those producing milk for the liquid milk market. Obviously, the Five-Point plan needs to be applied more rigorously if milk quality standards are to improve. S. uberis was a major cause of subclinical mastitis in split-calving herds and particularly in herds where housing conditions were suboptimal.

\section{Acknowledgements}

Funding provided by Schering Plough Animal.The authors acknowledge the work of the late Michael Nugent in bacteriological analysis and Aidan Kelly for technical assistance. Finally, the authors wish to acknowledge the farmers and veterinary surgeons who participated in the study.

\section{References}

Augnier, S.P.M. (1985). A Study of Bovine Mastitis Under Intensive Management Conditions. MVM Thesis, National University of Ireland.

Bradley, A.J. (2002). Bovine mastitis: an evolving disease. Veterinary Journal 164: I16-128.

Bradley,A.J. and Green, M.J. (2001). Aetiology of clinical mastitis in six Somerset dairy herds. Veterinary Record I 48: 683-686.

Bramley, A.J. (1982). Sources of Streptococcus uberis in the dairy herd. Journal of Dairy Research 49: 369-373.
Eberart, R.J. (1984). Coliform mastitis. Veterinary Clinics of North America: Food Animal Practice 6: 287-300.

Edmondson, P.W. (1989). An economic justification of 'blitz' therapy to eradicate Streptococcus agalactiae from a dairy herd. Veterinary Record 125: 591-593.

Egan, J. and O' Dowd, M. (1982). The mastitis status of autumncalving cows in two liquid milk areas. Irish Journal of Agricultural Research 21: 13-17.

Hillerton, J.E. (200I). Mastitis control in the UK. Bulletin of the IDF 367/200 I: 40-42.

Hillerton, J.E., Bramley, A.J., Staker, R.T. and McKinnon, C.H. (1995). Patterns of intramammary infection and clinical mastitis over a 5-year period in a closely monitored herd applying mastitis control measures. Journal of Dairy Research 62: 39-50.

Kossaibati, M.A. (2000). The costs of clinical mastitis in UK dairy herds. Cattle Practice 8: 323-328.

Meaney, W.J. (200I). Mastitis control in Ireland. Bulletin of the IDF 367/200I, 21-22.

Milne, M.H., Barrett, D.C., Fitzpatrick, J.L. and Biggs, A.M. (2002). Prevalence and aetiology of clinical mastitis on dairy farms in Devon. Veterinary Record I 5 I: 24 I-243.

Quinn, P.J., Markey, B.K., Carter, M.E., Donnelly, W.J. and Leonard, F.C. (2002). Veterinary Microbiology and Microbial Disease. London: Blackwell Science.

Schalm, O.W. and Noorlander, D.O. (1957). Experiments and observations leading to development of the California Mastitis Test. Journal of the American Veterinary Medical Association I30: 199- 207.

Sears, P.M., Smith, B.S., English, P.B., Herer, P.S. and Gonzalez, R.N. (1990). Shedding pattern of Staphylococcus aureus from bovine intramammary infections. Journal of Dairy Science 73: 2785-2789.

Smith, K.L. (1986). A practical look at environmental mastitis. Bovine Practitioner 21: 73- 76.

Watts, J.L. and Owens, W.E. (1989). Prevalence of staphylococcal species in four dairy herds. Research in Veterinary Science 46: I-4. 